\title{
Salinity tolerance of Calanus euxinus in the Black and Marmara Seas
}

\author{
Leonid Svetlichny ${ }^{1, *}$, Elena Hubareva ${ }^{1}$, Melek Isinibilir ${ }^{2}$, Ahmet Kideys ${ }^{3}$, \\ Genuario Belmonte ${ }^{4}$, Elisa Giangrande ${ }^{4}$ \\ ${ }^{1}$ Institute of Biology of the Southern Seas, National Academy of Sciences of Ukraine, Sevastopol, 99011, Crimea, Ukraine \\ ${ }^{2}$ Istanbul University, Faculty of Fisheries, Laleli, Istanbul, Turkey \\ ${ }^{3}$ Institute of Marine Sciences, Middle East Technical University, Erdemli, Turkey \\ ${ }^{4}$ CoNISMa, Stazione di Biologia Marina, Dipartimento di Biologia, Università degli Studi di Lecce, Italy
}

\begin{abstract}
We investigated how stenohalinic Black Sea Calanus euxinus, when migrating to the north-eastern Marmara Sea, can adapt to the pronounced salinity gradient there. During field observations (2005 to 2008) females of Calanus euxinus with significantly smaller body length (compared with those inhabiting the brackish Black Sea at 17 to $18 \mathrm{psu}$ ) were found in the deep, high-saline ( $38.5 \mathrm{psu})$ layers of the Marmara Sea. Similar diameters of eggs laid by small- and large-sized females and similar respiration rates in nauplii hatched from these eggs indicated the Black Sea origin of the $C$. euxinus population found in the Marmara Sea. To understand the morphological and physiological changes in $C$. euxinus during acclimation to high salinity, we studied the effect of salinity on behaviour, food consumption, growth patterns, hatching success and respiration rate of $C$. euxinus individuals collected in the Black and Marmara Seas. It was shown that the range of salinity tolerance for adult $C$. euxinus (17 to $30 \mathrm{psu}$ ) from the Black Sea was extended gradually to 40 psu after $1 \mathrm{~d}$ of acclimation to the high salinity of the Marmara Sea. Long-term parental salinity acclimation facilitates survival of eggs descending through the salinity gradient of the Marmara Sea, from brackish upper layers to deep, high-saline strata, or eggs laid in deep layers. While weight-specific respiration rates at the same temperature did not differ for $C$. euxinus juveniles from the Black and Marmara Seas, they were $\sim 2$ times higher in preadults and adults from the Marmara Sea than from the Black Sea. This may be the reason for the decrease in length and weight increments of these stages probably leading to the small-sized individuals of the seasonal $C$. euxinus population inhabiting the Marmara Sea.
\end{abstract}

KEY WORDS: Calanus euxinus - Salinity tolerance $\cdot$ Behaviour $\cdot$ Hatching success $\cdot$ Respiration Black Sea $\cdot$ Marmara Sea

Resale or republication not permitted without written consent of the publisher

\section{INTRODUCTION}

Calanus euxinus is considered to be a phenotypic variation of $C$. helgolandicus (Papadopoulos et al. 2005, Unal et al. 2006) widely distributed in the seas of the North Atlantic. The individuals of $C$. euxinus from the Black Sea population are considerably larger than C. helgolandicus specimens from the Mediterranean Sea (Fleminger \& Hulsemann 1987) and can accumulate more reserved lipids (up to $30-40 \%$ of body wet weight) in the oil sac (Svetlichny et al. 2009). C. euxinus is an important component of the diet of pelagic planktivorous fish in the Black Sea, including anchovy and sprat (Svetovidov 1964).
Although morphological differences between Calanus euxinus and $C$. helgolandicus are subtle, some authors (Tarkan \& Erguven 1988, Benli et al. 2001, Tarkan et al. 2005) identified both species in the Marmara Sea zooplankton, probably attributing larger and smaller individuals to $C$. euxinus and C. helgolandicus, respectively. However, Isinibilir et al. (2009) suggested that small-sized males and females in the Marmara Sea are actually not $C$. helgolandicus but Black Sea $C$. euxinus after accelerated development in an environment with higher temperature and salinity.

Due to a positive water balance in the Black Sea, its water masses are transferred into the Marmara Sea through the Bosphorus, forming a brackish surface 
layer (15 to $20 \mathrm{~m}$ ) with a salinity of 18 to $22 \mathrm{psu}$ and a temperature ranging from 20 to $24^{\circ} \mathrm{C}$ in summer and from 8 to $9^{\circ} \mathrm{C}$ in winter. Below this layer, there is more saline ( 38.5 psu) Mediterranean Sea water, with a constant temperature of $\sim 15^{\circ} \mathrm{C}$ throughout the year (Besiktepe et al. 1994).

In the Black Sea, late copepodite stages of Calanus euxinus perform daily vertical migrations with an amplitude of approximately $100 \mathrm{~m}$ (Vinogradov et al. 1992a, Besiktepe 2001). At night they aggregate in the oxygenated surface layer with temperatures of 6 to $8^{\circ} \mathrm{C}$ and from 22 to $25^{\circ} \mathrm{C}$ during the periods of winter to spring homothermy and late spring to autumn stratification, respectively. In the morning $C$. euxinus descend to a deep (80 to $180 \mathrm{~m}$ ), oxygen-deficient layer, with a constant temperature of 7 to $8^{\circ} \mathrm{C}$ all year round. During vertical migrations $C$. euxinus undergo slight salinity changes, because the salinity in the Black Sea increases with depth from 18 to 22 psu.

On the contrary, in the Marmara Sea, Calanus euxinus migrating vertically will experience pronounced salinity changes from 18 to 38.5 psu. Therefore, $C$. euxinus either adapted to living in a salinity gradient or is confined within a narrow brackish subsurface layer.

To understand the mechanism of acclimation of Black Sea Calanus euxinus to the specific conditions in the Marmara Sea, we conducted field observations of the population structure and vertical distribution of this species in the Marmara Sea and performed laboratory experiments to study the physiological and behavioural responses of $C$. euxinus from the Black and Marmara Seas to salinity changes.

\section{MATERIALS AND METHODS}

Copepod sampling. Field observations of Calanus euxinus living in the Marmara Sea were made in April and October 2005, November 2006, February, June and November 2007, and April 2008. Zooplankton samples were collected during daytime with a closing Nansen net (opening diameter: $50 \mathrm{~cm}$, mesh size: $200 \mu \mathrm{m})$ during the cruises of Hedef-1 at the permanent station in the north-eastern part of the Marmara Sea ( $40^{\circ} 51^{\prime} 53^{\prime \prime}$ N, $28^{\circ} 57^{\prime} 44^{\prime \prime}$ E). Sampling was carried out separately from the upper layer (0 to $25 \mathrm{~m}$ ) formed by Black Sea waters (salinity between 18.7 and $23.2 \mathrm{psu}$ ), the intermediate layer (25 to $50 \mathrm{~m}$ ), and the strata below the halocline (50 to $200 \mathrm{~m}$ ) consisting of Mediterranean Sea waters (with a salinity of $\sim 38 \mathrm{psu}$ and a temperature of $15^{\circ} \mathrm{C}$ ). In the Black Sea, C. euxinus were collected seasonally (from 2002 to 2007) near Sevastopol $\left(40^{\circ} 39^{\prime} 52^{\prime \prime} \mathrm{N}, 33^{\circ} 24^{\prime} 30^{\prime \prime} \mathrm{E}\right)$ in the 0 to $80 \mathrm{~m}$ layer (salinity of $18 \mathrm{psu}$ ). The samples were preserved with $4 \%$ borax-buffered formaldehyde. In the laboratory, each sample was completely transferred to a Bogorov chamber, numbers of individuals were determined for each developmental stage, and prosome lengths were measured under a dissecting microscope.

Laboratory experiments. Laboratory studies concerning the effect of salinity changes on the physiological and behavioural characteristics (egg survival, development time, respiration rate, gut fullness, frequency and duration of locomotor patterns in preadults and adults) of Calanus euxinus from the Black and Marmara Seas were conducted in autumn to spring from 2002 to 2008 and in every sampling period from 2005 to 2008, respectively. For comparison, the respiration rate of the closely related $C$. helgolandicus collected in the 0 to $30 \mathrm{~m}$ layer of the Ionian Sea near Taranto was examined in March $2009\left(\sim 13^{\circ} \mathrm{C}\right.$ surface temperature).

After sampling, copepodites and adults of Calanus euxinus were sorted using a wide-mouth pipette and incubated during nighttime at $8^{\circ} \mathrm{C}$ in $1.0 \mathrm{l}$ aquaria filled with $0.45 \mu \mathrm{m}$ filtered natural seawater containing an excess of food (dinoflagellate Prorocentrum minimum), at salinities from 17 to 18 psu and from 18 to 22 psu for the inhabitants of the Black and Marmara Seas, respectively.

Effect of salinity on locomotion. To study the salinity tolerance of C. euxinus from the Black Sea, we analyzed changes in locomotion parameters in response to gradual changes in salinity ranging from 17 to $40 \mathrm{psu}$. Water with high salinities was obtained by adding artificial sea salt to filtered Black Sea water.

In the morning, 20 to 30 individuals were placed in $100 \mathrm{ml}$ beakers and acclimated to $20^{\circ} \mathrm{C}$ for $1 \mathrm{~h}$. After that, 10 actively moving animals were selected and put into 10 crystallizing dishes containing $20 \mathrm{ml}$ of $0.45 \mu \mathrm{m}$ filtered seawater. During the experiment, the individuals were exposed to gradual salinity changes by transfer to seawater with a salinity value differing (2 to $3 \mathrm{psu}$ ) from the former value.

The locomotion parameters (frequency of mouth appendage movements, $\mathrm{Hz}_{\text {; }}$ time spent swimming, percent of total observation time) were examined in preadult and adult free-swimming (in $20 \mathrm{ml}$ beakers) Calanus euxinus individuals using a photodiode in the microscope ocular combined with an impulse counter and a storage oscilloscope. The frequency of elementary acts in the locomotor pattern was calculated as $F_{\mathrm{L}}=1 / D_{\mathrm{a}}$, where $D_{\mathrm{a}}$ was the mean duration of the locomotor act calculated from 10 sequential measurements. Time spent swimming was determined as $T=$ $D_{\mathrm{a}} n_{\mathrm{a}}$, where $n_{\mathrm{a}}$ was the number of locomotor acts. The measurements of locomotor parameters were conducted just after each salinity change and at the end of the exposure to a given salinity. 
Two treatments were used in the experiments with Calanus euxinus from the Black Sea: (1) salinity was increased gradually from 17 to between 38 and 40 psu at a rate of $3 \mathrm{psu} \mathrm{h}^{-1}$ for $8 \mathrm{~h}$. Copepods were kept at this salinity for $\sim 20 \mathrm{~h}_{\text {; }}$ (2) salinity was lowered gradually from between 38 and 40 to 17 psu at a rate of 3 to 4 psu for 6 to $8 \mathrm{~h}$. The rate of salinity change was calculated taking into account that, at a minimum gravity sinking speed of $7 \mathrm{~m} \mathrm{~h}^{-1}$ (Stepanov \& Svetlichny 1981), C. euxinus copepodites should descend from upper brackish layers to the deep, high-saline strata in 7 to $8 \mathrm{~h}$, whilst they spend not less than $3 \mathrm{~h}$ for ascending to the surface (Svetlichny et al. 2000). During all stages of the experiments, algae (Prorocentrum minimum) were added to the seawater to maintain an algal concentration of $\sim 300 \mu \mathrm{g} \mathrm{C}^{-1}$. After long-term salinity experiments $(8 \mathrm{~h})$, survival of $C$. euxinus individuals was examined over 2 to $3 \mathrm{~d}$.

To investigate salinity tolerance of Calanus euxinus from the Marmara Sea, we studied locomotory characteristics after salinity changes ranging from 22 to 52 psu. Water with high and low salinities was obtained by adding artificial sea salt to the Marmara Sea water or diluting it with de-ionized freshwater, respectively.

Two treatments were used: (1) salinity was increased gradually from 22 to $52 \mathrm{psu}$ at a rate of $6 \mathrm{psu} \mathrm{h}^{-1}$ for $5 \mathrm{~h}$; (2) salinity was decreased gradually from 38.6 to $22 \mathrm{psu}$ at a rate of 8 to $10 \mathrm{psu} \mathrm{h}^{-1}$ for $\sim 2 \mathrm{~h}$. We used higher rates of salinity change in the experiments with Calanus euxinus from the Marmara Sea, because, during preliminary studies, such individuals survived direct transfer from 22 to 39 psu and vice versa, in contrast to Black Sea C. euxinus.

In total 18 and 17 experiments to study locomotory activity were conducted with Calanus euxinus from the Black and Marmara Seas, respectively.

To estimate the effect of salinity change on the direction of swimming, 3 to 5 females of Calanus euxinus kept in $0.5 \mathrm{l}$ aquaria were exposed to a salinity increase from 18 to $40 \mathrm{psu}$ at a rate of $2.8 \mathrm{psu} \mathrm{h}^{-1}$ for $8 \mathrm{~h}$.

Feeding experiments. Salinity changes (from 17 to $37 \mathrm{psu}$ and from 22 to 38.5 psu for the Black and Marmara Sea Calanus euxinus, respectively) were performed progressing according to the feeding activity of female copepods (placed in $100 \mathrm{ml}$ beakers). If the females stopped consuming the dinoflagellate Prorocentrum minimum after a salinity change, they were kept at this salinity until recovery of their ability to feed and, only after that, the salinity was increased again. In long-term experiments the feeding activities of Black Sea females were studied with salinity changes from 17 to $27 \mathrm{psu}$ at a rate of $2 \mathrm{psu} \mathrm{h}^{-1}$ for $5 \mathrm{~h}$. Copepods were kept at 27 psu for $\sim 20 \mathrm{~h}$, and afterwards salinity was again increased gradually to up to
$37 \mathrm{psu}$. Gut fullness (\%) was estimated as the ratio of the amount of food consumed to the volume of the anterior part of the gut (calculated from the length and width of the gut measured using the images taken by the microscope's digital camera DSM 500). The dinoflagellates Prorocentrum minimum retained their mobility at salinities of 17 to 38.5 psu.

Hatching success. Survival of eggs produced by Calanus euxinus females from the Black and Marmara Seas during $7 \mathrm{~d}$ (in $100 \mathrm{ml}$ beakers at 8 to $10^{\circ} \mathrm{C}$ ) after a gradual long-term (over $30 \mathrm{~h}$ ) salinity change from 17 to 37 psu and from 22 to 38.5 psu, respectively, was examined. Hatching success (\%) was determined by counting the number of hatched nauplii and unhatched eggs over an incubation period of $4 \mathrm{~d}$ after egg laying.

Growth experiment. To study the effect of high salinity on growth and development of Black Sea Calanus euxinus, a laboratory generation of this species reared from eggs laid by females collected in the Black Sea and acclimated to $37 \mathrm{psu}$, was maintained at a salinity of 38 to $39 \mathrm{psu}$ and a temperature of 17 to $19^{\circ} \mathrm{C}$ in a $2 \mathrm{l}$ aquarium fed in excess with Prorocentrum minimum and Thalassiosira weisflogii. During the growth experiment, stage duration and prosome length of the individuals of every developmental stage were registered.

Measurements of respiration rate. Respiration rate $\left(R, \mathrm{mg} \mathrm{O}_{2}\right.$ ind $\left.^{-1} \mathrm{~h}^{-1}\right)$ of copepods was determined using closed respirometry, with experimental and control syringes of $2.0 \mathrm{ml}$ as respirometers. We transferred 20 to 30 nauplii of Stages IV to VI (NIV to NVI), 4 to 10 copepodites of Stages I to IV (CI to CIV), 1 copepodite of Stage $\mathrm{V}(\mathrm{CV})$ or an adult female (CVIF) or male (CVIM) by pipette into an experimental syringe filled with filtered seawater with a protective sieve disc (mesh size: $200 \mu \mathrm{m}$ ) before the confluent outlet. In order to obtain identical initial oxygen, salinity and seston content in both the control and experimental syringes, we connected the syringes with a plastic tube and pumped the water through it several times. Then the syringes were separated, closed by the stoppers and placed into a dark chamber at either $20 \pm 0.5$ or 8 $\pm 0.5^{\circ} \mathrm{C}$. Incubation periods were from 2 to $3 \mathrm{~h}$ for nauplii and Copepodites I to III and 1 to $2 \mathrm{~h}$ for Copepodites IV to VI. There were no less than 10 replicates for nauplii and for every size groups of Copepodites I to VI from the Black and Marmara Seas.

At the end of the exposure, water samples from each the experimental and control syringe were transferred to the respirometer chamber; an all-glass syringe of $0.5 \mathrm{ml}$ volume joined with a polarographic membrane oxygen sensor with a magnetic stirrer inside. The oxygen concentration and respiration rate were measured according to the method described in Svetlichny \& Hubareva (2005) and Svetlichny et al. (2009). 
To study basal metabolism, we narcotized Calanus euxinus females from the Black and Marmara Seas and C. helgolandicus females from the Ionian Sea by $\mathrm{MgCl}_{2}\left(15 \mathrm{~g} \mathrm{l}^{-1}\right)$ diluted in seawater with a final salinity of 17, 21.8 and $39 \mathrm{psu}$, respectively. The copepods were kept under these conditions until complete immobilization. After that, $C$. euxinus individuals were transferred to experimental syringes with lower concentrations of $\mathrm{MgCl}_{2}\left(5 \mathrm{~g} \mathrm{l}^{-1}\right)$ and incubated at $20^{\circ} \mathrm{C}$ for 2 to $3 \mathrm{~h}$, depending on the number of individuals, while measuring the respiratory rate. This concentration of $\mathrm{MgCl}_{2}$ was sufficient to keep copepods immobile during exposure. After incubation, the individuals, transferred to seawater without $\mathrm{MgCl}_{2}$, gradually recovered their locomotor activity after 0.5 to $1 \mathrm{~h}$.

Length-weight measurements. To express ontogenetic changes in respiration rate of nauplii and copepodites taking into account body wet weight (WW, mg) and structural carbon body weight (SCW, mg), we calculated the wet weight of nauplii as $\mathrm{WW}=V_{\mathrm{b}} \rho$, where $V_{\mathrm{b}}$ was the body volume $\left(\mathrm{mm}^{3}\right)$ and $\rho$ was the mean density amounting to $1.06 \mathrm{mg} \mathrm{cm}^{-3}$. $V_{\mathrm{b}}$ for Nauplii III to VI was determined using the empiric equation: $V=0.058 L_{\mathrm{pr}}^{2.66}$ (see 'Results: Weight-length relationships ...'), where $L_{\text {pr }}$ was prosome length (mm). The equation was based on direct measurements of the diameter of a microscopic seawater drop (measured under a light microscope; magnification $200 \times$ ) before and after placing a nauplius into it. To obtain a regular spherical form, the drop of seawater was put into a mixture of chloroform and castor oil with a density being equal to that of seawater. Nauplii were dried a little and then transferred into the drop of seawater. The volume of the drop was calculated using the formula for the volume of a sphere.

The body volume of copepodites of all stages was calculated as $V_{\mathrm{b}}=k L_{\mathrm{pr}} d_{\mathrm{pr}}{ }^{2}$, where $d_{\mathrm{pr}}$ is the diameter of the prosome (mm) and $k$ is the empiric coefficient of 0.64 in males and 0.58 in copepodites and females (Svetlichny 1983). The body wet weight of Calanus euxinus copepodites and females was also calculated using the data of body volume and taking into account the mean body density determined as $\rho=1.06-$ $0.0016 \mathrm{SV}_{\mathrm{s}}$, where $\mathrm{SV}_{\mathrm{s}}(\%)$ is the share of the oil sac in the body volume determined as reported by Svetlichny et al. $(1998,2009)$. Length and width of the prosome were measured to the nearest $10 \mu \mathrm{m}$ under a dissecting microscope fitted with an eyepiece micrometer.

The SCW of copepodites and adults of Black Sea Calanus euxinus were estimated as $\mathrm{SCW}=\mathrm{WW} \times \mathrm{CF}$, where $\mathrm{CF}$ is a structural condition factor for every copepodite stage. CF was determined using the equation $\mathrm{CF}=\mathrm{CW}-\mathrm{CWE} / \mathrm{WW}$, where $\mathrm{CW}$ is the body carbon weight and CWE is the carbon weight of the wax esters (Svetlichny et al. 2009). For copepodites and adults of Marmara Sea C. euxinus, SCW was calculated using the regression between the prosome length $\left(L_{\mathrm{pr}}, \mu \mathrm{m}\right)$ and SCW $(\mu \mathrm{g})$ established for $C$. helgolandicus copepodites as SCW $=\left(2.133 \times 10^{-8}\right) L_{\mathrm{pr}}^{2.79}$ (Rey-Rassat et al. 2004). For nauplii from the Black and Marmara Seas, SCW was determined following the equation: $C=\left(3.93 \times 10^{-6}\right) L_{\mathrm{pr}}^{1.98}$ established by ReyRassat et al. (2004) for total carbon content $(C)$ in $C$. helgolandicus nauplii because the nauplii of this species do not accumulate wax esters. In fact, the line of the regression between length and the SCW of C. euxinus copepodites was the continuation of the line of the regression between length and $C$ in nauplii of $C$. helgolandicus (see Fig. 2).

Statistical evaluation of data was conducted by 1 -way ANOVA and Student's $t$-test. Values presented in the figures and tables are means $\pm \mathrm{SD}$.

\section{RESULTS}

\section{Field observations}

In the Marmara Sea near the Prince Islands, the maximum total abundance of Calanus euxinus in the period from 2005 to 2008 was reported in April 2005 (1260 ind $\mathrm{m}^{-2}$ ). In other periods of our study the number of $C$. euxinus varied from 30 to 178 ind. $\mathrm{m}^{-2}$. Although individuals of this species were found throughout the whole water column, the main portion of the $C$. euxinus population $(58.4 \pm 17.4 \%$, mean $\pm \mathrm{SD})$ aggregated in the upper layer (0 to $25 \mathrm{~m}$ ) formed by Black Sea waters (Table 1). Proportions of $19.7 \pm 12.1$ and $21.9 \pm 12.3 \%$ of the total number of $C$. euxinus were in the intermediate ( 25 to $50 \mathrm{~m}$ ) and the deep (50 to $200 \mathrm{~m}$ ) layers formed by more saline (up to $38.5 \mathrm{psu}$ ) waters from the Mediterranean Sea, respectively.

In April 2005, the age structure of the Calanus euxinus population of the Marmara Sea was similar in the 3 different water layers, except the absence of Stage CI in the deep zone and males (CVIM) in the mixed, inter-

Table 1. Calanus euxinus. Vertical distribution of individuals in the Marmara Sea near the Prince Islands, expressed as a percentage of the total population in the water

\begin{tabular}{|llcr|}
\hline Date & \multicolumn{3}{c|}{ Sampling layer (m) } \\
& $0-25$ & $25-50$ & $50-200$ \\
\hline Apr 2005 & 53.5 & 15.9 & 30.6 \\
Oct 2005 & 53.6 & 28.5 & 17.9 \\
Nov 2006 & 61.8 & 1.7 & 36.5 \\
Feb 2007 & 80 & 13.3 & 6.7 \\
Jun 2007 & 58.1 & 19.4 & 22.5 \\
Nov 2007 & 26.7 & 40 & 33.3 \\
Apr 2008 & 75 & 18.8 & 6.2 \\
\hline
\end{tabular}




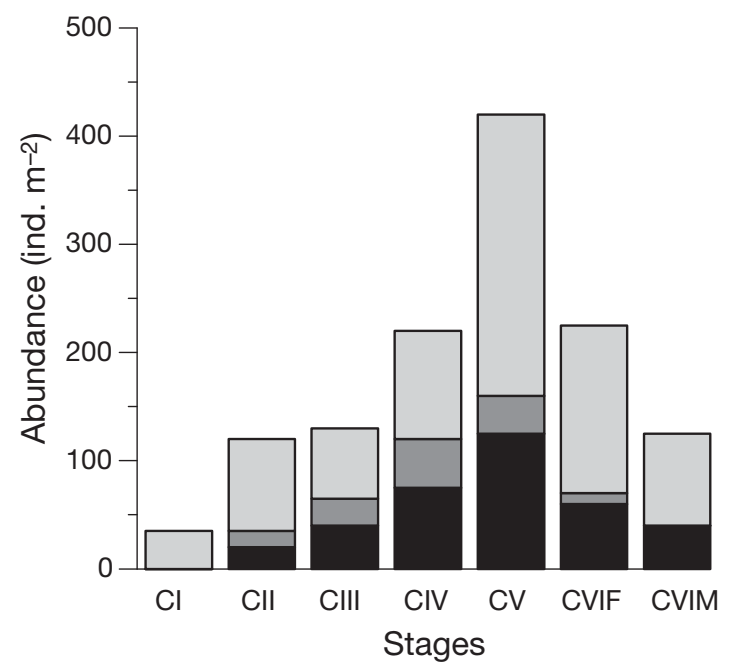

Fig. 1. Calanus euxinus. Abundance of different developmental stages from upper $(\square, 0$ to $25 \mathrm{~m})$, intermediate $(\square, 25$ to

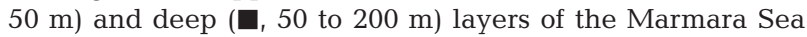
during April 2005

mediate layer (Fig. 1). The CVs and females dominated the population. We distinguished 3 size groups in females constituting $38 \%$ (prosome length of $2.01 \pm$ $0.04 \mathrm{~mm}$, mean $\pm \mathrm{SD}$ ), $48 \%$ (prosome length of $2.23 \pm$ $0.07 \mathrm{~mm}$ ) and $14 \%$ (prosome length of $2.50 \pm 0.09 \mathrm{~mm}$ ) of the total number.

Females from the first and second size groups occurred through all layers, whilst large individuals from the third group were only in the upper strata formed by Black Sea waters. All taxonomic characteristics for the 3 size groups of the Marmara Sea Calanus euxinus were identical. In April 2005, carcasses of $C$. euxinus were only found deeper than $50 \mathrm{~m}$ and amounted to $3.9 \%$ of the total abundance.

Prosome length of females $(2.63 \pm 0.14 \mathrm{~mm})$ collected in the spring of 2005 in the Black Sea near Sevastopol were significantly higher $(t$-test, $\mathrm{p}<0.001)$ than those from the deep layers of the Marmara Sea. During this period the mean prosome lengths in Stages N6 (0.64 \pm $0.04 \mathrm{~mm}), \mathrm{CI}(0.64 \pm 0.03 \mathrm{~mm})$ and CII $(0.96 \pm 0.05 \mathrm{~mm})$ collected in the Marmara Sea near the Prince Islands did not differ significantly ( $t$-test, $\mathrm{p}>0.05$ ) from those in Stages N6 $(0.66 \pm 0.04 \mathrm{~mm}), \mathrm{CI}(0.69 \pm 0.05 \mathrm{~mm})$ and CII $(0.94 \pm 0.05 \mathrm{~mm})$ sampled in the Black Sea near Sevastopol.

\section{Weight-length relationships in nauplii and copepodites of Calanus euxinus}

During naupliar development, body wet weight in stages NI to NIII from the Black Sea varied between 0.0022 and $0.0039 \mathrm{mg}$, irrespective of prosome length

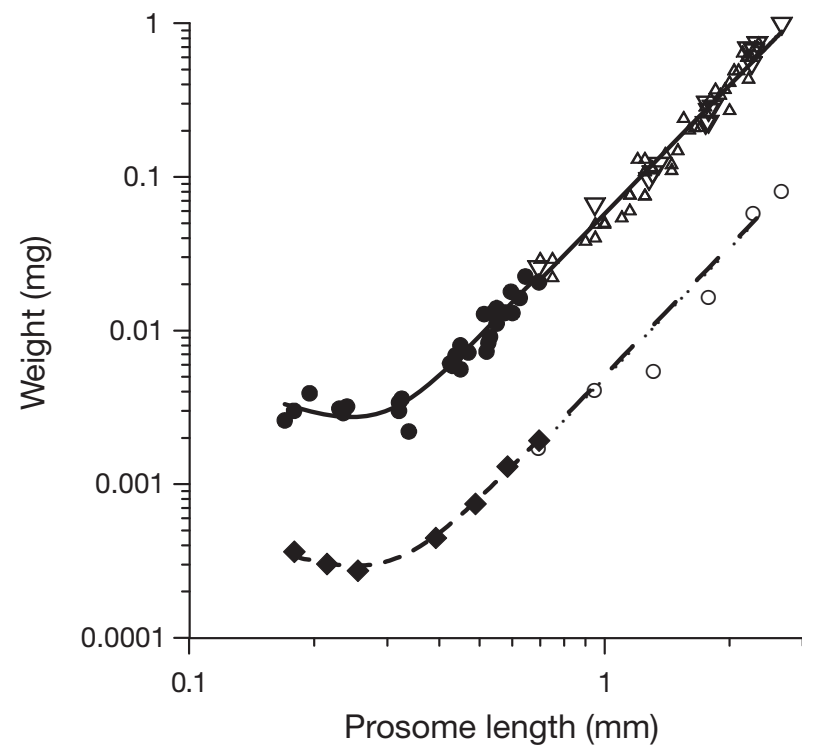

Fig. 2. Calanus euxinus. Wet body weight of nauplii from the Black Sea $(\bullet)$ and copepodites of $C$. euxinus from the Black $(\nabla)$ and Marmara $(\Delta)$ Seas, structural carbon weight in Copepodite Stages I to VI of $C$. euxinus from the Black Sea (O) (Svetlichny et al. 2009) and carbon content in nauplii of C. helgolandicus ( $\bullet$ (Rey et al. 2001)

which increased from 0.17 to $0.29 \mathrm{~mm}$. However, changes in prosome length from $0.425 \mathrm{~mm}$ for NIV to $0.695 \mathrm{~mm}$ for NVI resulted in an increase in body wet weight to $0.023 \mathrm{mg}$ (Fig. 2), following the equation $\mathrm{WW}=0.058 L_{\mathrm{pr}}^{2.66}\left(\mathrm{n}=23, \mathrm{r}^{2}=0.91\right)$. For Calanus euxinus copepodites from the Black and Marmara Seas, the relationship between body wet weight and prosome length can be described as WW $=0.058 L_{\mathrm{pr}}^{2.78}\left(\mathrm{r}^{2}=0.97\right.$, $\mathrm{n}=234)$ and $\mathrm{WW}=0.053 L_{\mathrm{pr}}^{2.91}\left(\mathrm{r}^{2}=0.96, \mathrm{n}=184\right)$, respectively.

\section{Effects of salinity}

\section{Locomotion}

In Calanus euxinus females and CVs sampled in deep layers of the Marmara Sea near the Prince Islands, time spent swimming did not change significantly during short-term $(4 \quad$ h) gradual salinity increases from 22 to $40 \mathrm{psu}$. Only in 9 experiments between 40 and 50 psu did we observe pronounced depression of locomotion, when both time spent swimming (Fig. 3A) and frequency of locomotor acts (Fig. 3B) was sharply reduced. We found no regular trends in changes in locomotor parameters of females and CVs kept for several days at 38.5 psu and then exposed to a short-term (up to $2.5 \mathrm{~h}$ ), gradual salinity decrease to $22 \mathrm{psu}$. During gradual increases and fur- 

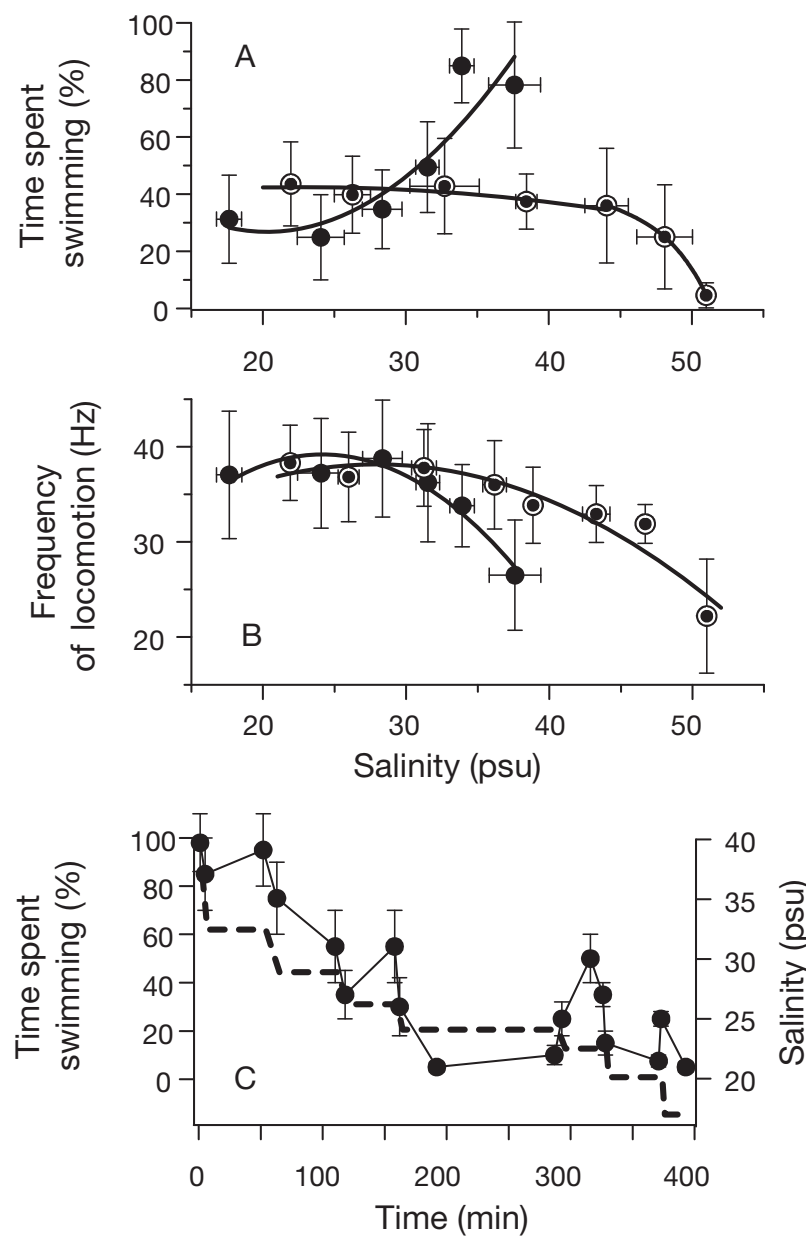

Fig. 3. Calanus euxinus. (A) Changes in time spent swimming and (B) frequency of locomotion in females from the Black Sea (•) during salinity increases ( $8 \mathrm{~h}$ ) from 17 to 40 psu and in CVs and females from the Marmara Sea (O) during salinity increases $(5 \mathrm{~h})$ from 22 to $52 \mathrm{psu}$. (C) Changes in time spent swimming in females from the Black Sea during salinity decreases from 37 to $17 \mathrm{psu}$. Solid line: best fit regression curves $(A, B)$; simple linkage curve $(C)$. Dashed line: salinity change. Values are means $\pm \mathrm{SD}$

ther decreases of salinity ranging from 22 to $38.5 \mathrm{psu}$, the copepods did not stop consuming food. C. euxinus even survived direct transfer from 22 to 39 psu.

In the $8 \mathrm{~h}$ locomotion activity experiments at $20^{\circ} \mathrm{C}$, Black Sea Calanus euxinus did not show disturbance during gradual salinity changes from 17 to between 25 and 27 psu. However, when salinity increased to between 37 and $40 \mathrm{psu}$, time spent swimming rose to a maximum value of $78 \pm 24 \%$ (mean $\pm \mathrm{SD}$ ) (Fig. $3 \mathrm{~A}$ ), while the frequency of locomotion decreased (Fig. 3B). Direction of swimming changed with increasing salinity as copepodites and adults of $C$. euxinus, usually aggregated near the bottom, ascended to the surface and constantly swam there after completion of the

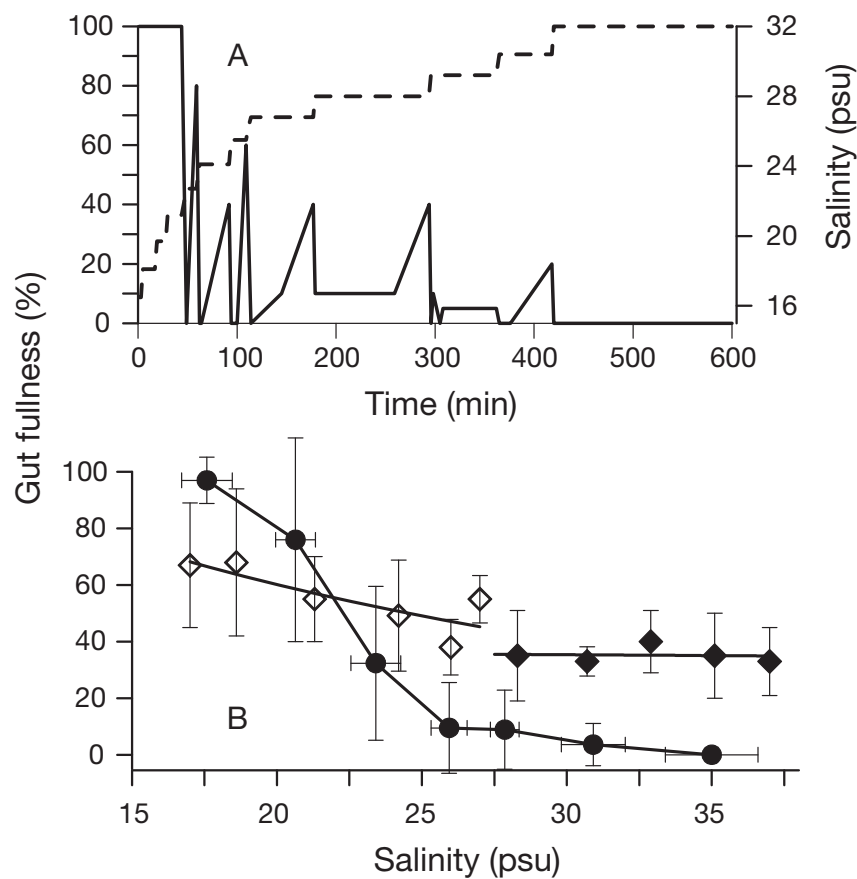

Fig. 4. Calanus euxinus. (A) Example of changes in gut fullness in 1 individual with gradual salinity increases from 17 to $37 \mathrm{psu}$ and (B) mean values of gut fullness for 6 different individuals during short-term $(\bullet)$ salinity increases from 17 to $37 \mathrm{psu}(8$ to $10 \mathrm{~h}$ ) and long-term salinity increases from 17 to 27 psu over $5 \mathrm{~h}(\diamond)$ and from 27 to 37 psu after keeping these individuals at $27 \mathrm{psu}$ for $20 \mathrm{~h}(\bullet)$. The most actively feeding females were used in short-term experiments. Dashed line: salinity change. Solid lines in (B): best fit regression curves $(\neg, \bullet-)$ or a simple linkage curve $(\bullet-)$. Values are means $\pm \mathrm{SD}$

salinity change. Although the copepods survived a salinity increase to up to $40 \mathrm{psu}$, they stopped feeding; the muscles of some individuals became opaque, indicating irreversible tissue changes. A decrease in salinity from 37 to 17 psu caused a reduction of the time spent swimming (Fig. 3C).

\section{Feeding behaviour}

In the $1.5 \mathrm{~h}$ feeding experiments, gradual salinity increases from 17 to 25 psu did not affect food consumption in Black Sea Calanus euxinus females. The anterior part of the gut was constantly full of algae in all individuals. During subsequent salinity increases, every change in salinity (by 2 to $3 \mathrm{psu}$ ) resulted in rapid gut evacuation (Fig. 4A). The duration of the salinity acclimation period changed from 15 to $40 \mathrm{~min}$ at 17 to $25 \mathrm{psu}$ to a period of from 80 to $120 \mathrm{~min}$ at 28 to $30 \mathrm{psu}$. Gut fullness decreased with increasing salinity, and, after short-term increase, $C$. euxinus females even completely stopped consuming algae at a salinity of 


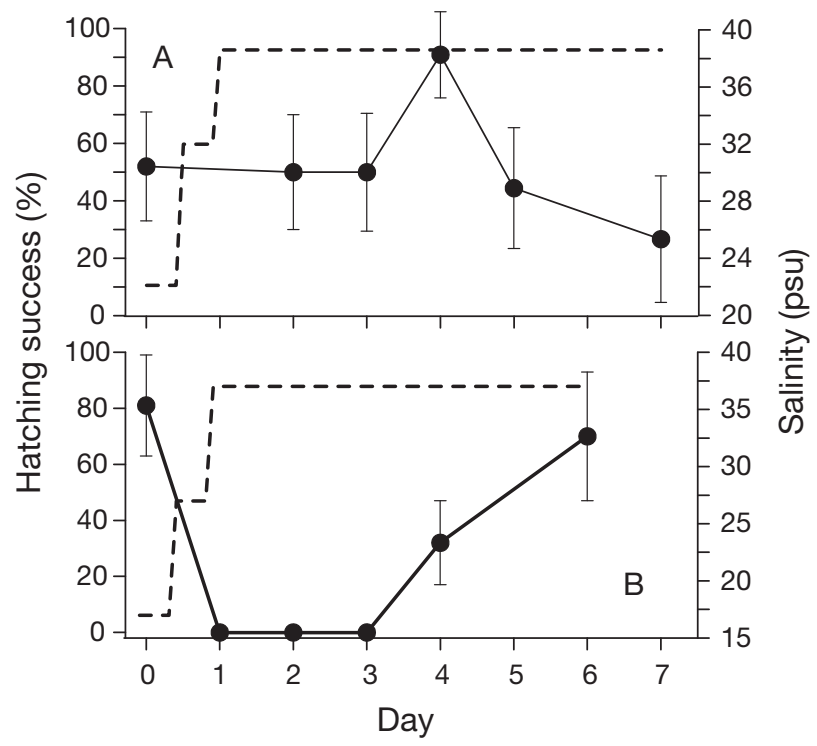

Fig. 5. Calanus euxinus. Hatching success of (A) eggs laid by small-sized females from the Marmara Sea after long-term salinity increases from 22 to 38.5 psu and (B) eggs laid by Black Sea females after long-term salinity increases from 17 to $37 \mathrm{psu}$. Dashed line: salinity change

$>31$ psu (Fig. 4B). However, after acclimation to $27 \mathrm{psu}$ over $\sim 20 \mathrm{~h}$, Black Sea $C$. euxinus still had the ability to feed and fill their guts even at 37 psu.

\section{Hatching success}

The diameters of eggs laid by small females (prosome length of 1.9 to $2.15 \mathrm{~mm}$, mean $\pm \mathrm{SD}$ ) collected in the Marmara Sea in December 2006 and by large females (prosome length of 2.6 to $2.7 \mathrm{~mm}$ ) collected in the same period in the Black Sea were similar (174.8 \pm 2.9 and $179.2 \pm 5.6 \mu \mathrm{m}$, respectively).

After long-term (up to $30 \mathrm{~h}$ ) gradual salinity changes from 22 to $38.5 \mathrm{psu}$, hatching success of eggs laid by Marmara Sea Calanus euxinus at 38.5 psu did not vary during the $6 \mathrm{~d}$ after salinity increase (except on the 4 th day of the experiment, with a hatching success of $91 \%$ ) and amounted to between 44 and $50 \%$. This value was similar to the hatching success of $52 \pm 19 \%$ at $22 \mathrm{psu}$ (Fig. 5A).

Similar long-term experiments were conducted with Black Sea Calanus euxinus. After gradual salinity increases from 17 to 37 psu over $30 \mathrm{~h}$, Black Sea females retained the ability to lay eggs. However, all eggs laid in the first $3 \mathrm{~d}$ at $37 \mathrm{psu}$ were nonviable. Nauplii developed from about $40 \%$ of the eggs laid on the 4 th day after a salinity increase to $37 \mathrm{psu}$; only after $6 \mathrm{~d}$ of parental acclimation to high salinity did the hatching success of eggs laid reach viability values

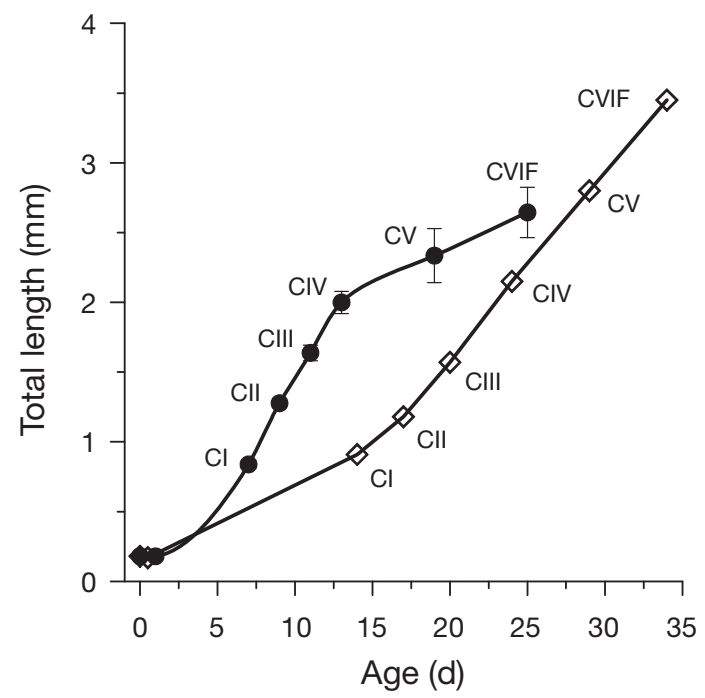

Fig. 6. Calanus euxinus. Increase in total body length relative to age at $18 \pm 1^{\circ} \mathrm{C}$ in our growth experiment at 38 to $39 \mathrm{psu}(\bullet)$ and in the experiments of Sazhina (1987) at $18 \mathrm{psu}(\diamond)$

comparable to eggs laid before the salinity increase (Fig. 5B).

In the growth experiment, development times from egg laying to $\mathrm{CI}$ and from CI to CIV amounted to 7 and $6 \mathrm{~d}$, respectively (Fig. 6), whilst the development from CIV to adult female took $12 \mathrm{~d}$. Total body length and prosome length of females were $2.64 \pm 0.18 \mathrm{~mm}$ and $2.05 \pm 0.14 \mathrm{~mm}$, respectively.

\section{Respiration rates}

At $20^{\circ} \mathrm{C}$ the weight-specific respiration rates (Q/WW, $\mu \mathrm{g} \mathrm{O}_{2} \mathrm{mg}^{-1} \mathrm{~h}^{-1}$ ) in females and males of Calanus euxinus from the Black Sea varied independent of the season within the range from 0.91 to $1.34 \mu \mathrm{g} \mathrm{O} \mathrm{mg}^{-1} \mathrm{~h}^{-1}$ (Table 2). The weight-specific respiration rates of C. euxinus females reared in the laboratory from eggs at $39 \mathrm{psu}\left(1.80 \pm 0.27 \mu \mathrm{g} \mathrm{O}_{2} \mathrm{mg}^{-1} \mathrm{~h}^{-1}\right)$, small $C$. euxinus collected in the deep layers of the Marmara Sea (1.71 to $1.92 \mu \mathrm{g} \mathrm{O}_{2} \mathrm{mg}^{-1} \mathrm{~h}^{-1}$ for females and 1.6 to $2.38 \mu \mathrm{g} \mathrm{O}_{2} \mathrm{mg}^{-1} \mathrm{~h}^{-1}$ for males) and C. helgolandicus females from the Ionian Sea $\left(1.61 \pm 0.27 \mu \mathrm{g} \mathrm{O}_{2} \mathrm{mg}^{-1}\right.$ $\mathrm{h}^{-1}$ ) were significantly ( $t$-test, $\left.\mathrm{p}<0.001\right)$ higher $(1.5-$ to 2 -fold) than the weight-specific respiration rates of C. euxinus sampled in the Black Sea.

The ratio between total metabolism and basal metabolism amounted to 2.6, 2.4 and 1.9 for females of Calanus euxinus from the Black and Marmara Seas and C. helgolandicus from the Ionian Sea, respectively. In narcotized females from the Marmara and Ionian Seas, the weight-specific respiration rates were 2 -fold higher (1-way ANOVA, $F_{2.9}=5, \mathrm{p}<0.05$ and $F_{7.4}=$ 
Table 2. Calanus euxinus, C. helgolandicus. The rate of wet-weight-specific respiration rate (Q/WW) at $20 \pm 0.5^{\circ} \mathrm{C}$ in $C$. euxinus females and males collected from the Black Sea (17 to $18.7 \mathrm{psu}$ ), the Black Sea C. euxinus females reared in the laboratory at $39 \mathrm{psu}$, the Marmara Sea C. euxinus females and males living at changing salinity (18.7 to 38.9 psu) near the Prince Islands, and the Ionian Sea C. helgolandicus females living at constant high salinity (39 psu). n: number of experiments. WW: wet weight. WW and $\mathrm{Q} / \mathrm{WW}$ are given as mean $\pm \mathrm{SD}$

\begin{tabular}{|c|c|c|c|c|c|}
\hline Date & $\begin{array}{l}\text { Habitat salinity } \\
\text { (psu) }\end{array}$ & $\begin{array}{l}\text { Experimental salinity } \\
\text { (psu) }\end{array}$ & $\mathrm{n}$ & $\begin{array}{l}\text { Wet weight } \\
\text { (mg) }\end{array}$ & $\begin{array}{c}\text { Q/WW } \\
\left(\mu \mathrm{O}_{2} \mathrm{mg}^{-1} \mathrm{~h}^{-1}\right)\end{array}$ \\
\hline \multicolumn{6}{|c|}{ Black Sea, female } \\
\hline Mar 2007 & & 18.7 & 38 & $1.08 \pm 0.10$ & $0.95 \pm 0.20$ \\
\hline Apr 2003 & \multirow{7}{*}{$17-20$} & 18.2 & 22 & $1.10 \pm 0.04$ & $1.34 \pm 0.36$ \\
\hline May 2005 & & 17.0 & 10 & $1.04 \pm 0.21$ & $1.01 \pm 0.16$ \\
\hline Jul 2008 & & 17.5 & 29 & $1.10 \pm 0.04$ & $1.25 \pm 0.36$ \\
\hline Sep 2003 & & 17.5 & 46 & $1.04 \pm 0.13$ & $1.02 \pm 0.27$ \\
\hline Oct 2002 & & 17.4 & 13 & $0.91 \pm 0.14$ & $0.91 \pm 0.10$ \\
\hline Nov 2006 & & 17.7 & 10 & $1.08 \pm 0.25$ & $1.17 \pm 0.36$ \\
\hline Nov $2006^{a}$ & & 17.0 & 10 & $1.07 \pm 0.06$ & $0.45 \pm 0.03$ \\
\hline \multirow[t]{2}{*}{ Dec 2004} & \multirow{2}{*}{39.0} & 39.0 & 20 & \multirow{2}{*}{$0.43 \pm 0.07$} & $1.80 \pm 0.27$ \\
\hline & & 17.0 & 9 & & $1.82 \pm 0.38$ \\
\hline \multicolumn{6}{|l|}{ Black Sea, male } \\
\hline Apr 2003 & \multirow{2}{*}{$17-20$} & 18.2 & 15 & $0.76 \pm 0.10$ & $1.15 \pm 0.20$ \\
\hline Oct 2002 & & 17.4 & 14 & $0.76 \pm 0.09$ & $1.19 \pm 0.27$ \\
\hline \multicolumn{6}{|c|}{ Marmara Sea, female } \\
\hline \multirow[t]{2}{*}{ Mar 2007} & \multirow[t]{2}{*}{$18.7-38.9$} & 18.7 & 6 & $0.39 \pm 0.09$ & $1.76 \pm 0.21$ \\
\hline & & 38.9 & 14 & $0.46 \pm 0.09$ & $1.67 \pm 0.34$ \\
\hline Apr/May 2005 & $22.1-38.6$ & 22.1 & 36 & $0.55 \pm 0.11$ & $1.71 \pm 0.29$ \\
\hline Oct 2005 & $23.2-38.7$ & 23.2 & 6 & $0.33 \pm 0.03$ & $1.78 \pm 0.51$ \\
\hline Dec 2006 & $21.8-38.6$ & 21.8 & 22 & $0.59 \pm 0.13$ & $1.92 \pm 0.57$ \\
\hline Dec $2006^{a}$ & $21.8-38.6$ & 21.8 & 10 & $0.66 \pm 0.16$ & $0.80 \pm 0.15$ \\
\hline \multicolumn{6}{|c|}{ Marmara Sea, male } \\
\hline Apr/May 2005 & $22.1-38.6$ & 22.1 & 18 & $0.57 \pm 0.10$ & $1.60 \pm 0.45$ \\
\hline Dec 2006 & $21.8-38.6$ & 21.8 & 6 & $0.47 \pm 0.02$ & $2.38 \pm 0.76$ \\
\hline \multicolumn{6}{|c|}{ Ionian Sea, female } \\
\hline Mar 2009 & $38.0-39.0$ & 39.0 & 21 & $0.64 \pm 0.08$ & $1.61 \pm 0.27$ \\
\hline Mar $2009^{a}$ & $38.0-39.0$ & 39.0 & 7 & $0.62 \pm 0.07$ & $0.87 \pm 0.25$ \\
\hline
\end{tabular}

Table 3. Temperature coefficient $Q_{10}$ for nauplii (N), copepodite stages (CI to CV) of Calanus euxinus (mean $\pm \mathrm{SD}$ ) from the Marmara and Black Seas and for other copepods. Blank cells: no data

\begin{tabular}{|c|c|c|c|c|c|c|c|}
\hline \multirow{2}{*}{ Area } & \multirow{2}{*}{$\begin{array}{l}\text { Experimental } \\
\text { salinity (psu) }\end{array}$} & \multirow[b]{2}{*}{$\mathrm{N}$} & \multirow[b]{2}{*}{ CI-II } & \multirow{2}{*}{$\begin{array}{l}\text { Stages } \\
\text { CIII-IV }\end{array}$} & \multirow[b]{2}{*}{$\mathrm{CV}$} & \multirow[b]{2}{*}{ Female } & \multirow{2}{*}{ Sources } \\
\hline & & & & & & & \\
\hline \multicolumn{8}{|l|}{ Calanus euxinus } \\
\hline Marmara Sea & 22 & $1.97 \pm 0.33$ & $1.87 \pm 0.26$ & $1.69 \pm 0.19$ & $2.35 \pm 0.48$ & $1.96 \pm 0.28\}$ & \\
\hline Black Sea & 18 & $1.89 \pm 0.45$ & & & & $1.85 \pm 0.22\}$ & Present study \\
\hline Black Sea & 18 & & & & & 2.05 & Svetlichny et al. (2000) \\
\hline \multicolumn{8}{|l|}{ Calanus pacificus } \\
\hline Pacific Ocean & 30 & & & & & 1.8 & Vidal (1980) \\
\hline \multicolumn{8}{|l|}{ Marine copepods } \\
\hline $\begin{array}{l}\text { Atlantic, Indian, Pacific } \\
\text { Oceans }\end{array}$ & 34 & & & & 1.8 & -2.1 & Ikeda et al. (2001) \\
\hline
\end{tabular}

10.67, $\mathrm{p}<0.01$, respectively) than that in narcotized individuals from the Black Sea.

The weight-specific respiration rates in Black Sea females reared from eggs at 39 psu were $1.82 \pm 0.38 \mu \mathrm{g}$ $\mathrm{O}_{2} \mathrm{mg}^{-1} \mathrm{~h}^{-1}$ (mean $\pm \mathrm{SD}$ ) $4 \mathrm{~d}$ after a gradual salinity

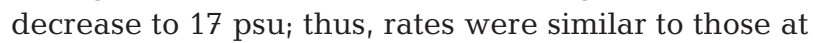
high salinity. The Marmara Sea females collected from deep layers (38.5 psu) and kept under laboratory conditions $\left(20^{\circ} \mathrm{C}\right)$ at a salinity of 38.5 or 22 psu did not differ significantly in weight-specific respiration rates, which varied in the range of from 1.56 to $1.97 \mu \mathrm{g} \mathrm{O}_{2}$ $\mathrm{mg}^{-1} \mathrm{~h}^{-1}$ over $13 \mathrm{~d}$. At $7^{\circ} \mathrm{C}$, the weight-specific respiration rate of Marmara Sea Calanus euxinus females was 2.6-fold lower than at $20^{\circ} \mathrm{C}$ (Fig. 7). 


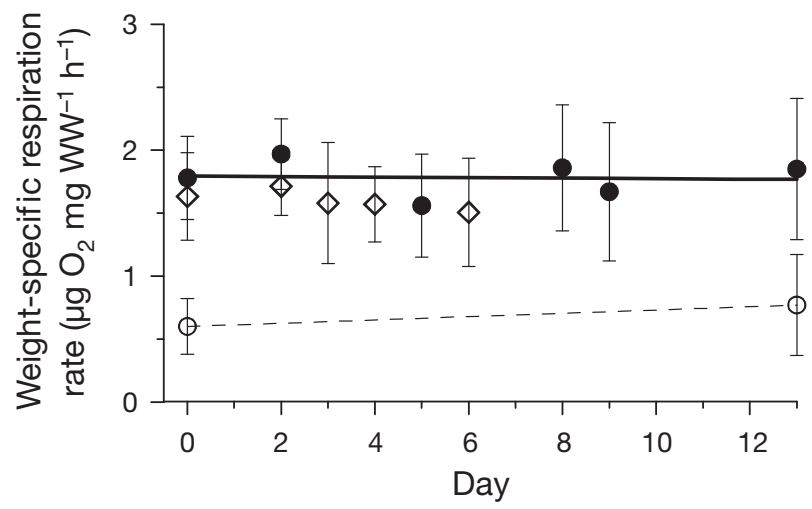

Fig. 7. Calanus euxinus. Wet-weight-specific respiration rate in small-sized females from deep layers of the Marmara Sea at experimental salinities of $22 \mathrm{psu}(\bullet)$ and $38.6 \mathrm{psu}(\diamond)$ and a temperature of $20^{\circ} \mathrm{C}$ and at $22 \mathrm{psu}(\mathrm{O})$ and $7^{\circ} \mathrm{C}$. Solid line: linear regression curve. Dashed line: simple regression curve.

Values are means \pm SD (bars). WW: wet weight

The temperature coefficient $\left(Q_{10}\right)$ obtained in the range from $7.5 \pm 0.5$ to $20 \pm 0.5^{\circ} \mathrm{C}$ equalled from 1.69 to 2.35 for different developmental stages of Calanus euxinus from the Marmara Sea. $Q_{10}$ of nauplii (1.89 \pm $0.45)$ and females $(1.85 \pm 0.22)$ from the Black Sea were similar to the corresponding values for Marmara Sea individuals (Table 3).

The respiration rate of Calanus euxinus from the Marmara Sea increased from $0.024 \pm 0.005 \mathrm{\mu g} \mathrm{O}_{2}$ ind. $^{-1}$ $\mathrm{h}^{-1}$ in nauplii (developed from eggs laid by small females) to $1.29 \pm 0.49 \mu \mathrm{g} \mathrm{O}_{2}$ ind..$^{-1} \mathrm{~h}^{-1}$ in females (with a wet weight of $0.679 \pm 0.028 \mathrm{mg}$ ), following the equation: $R=1.67 \mathrm{WW}^{0.90}$ (Fig. 8A). In C. euxinus collected in the Black Sea the respiration rate rose from $0.033 \pm$
$0.008 \mu \mathrm{g} \mathrm{O}_{2}$ ind. $^{-1} \mathrm{~h}^{-1}$ in nauplii to $0.088 \pm 0.036 \mu \mathrm{g} \mathrm{O} \mathrm{O}_{2}$ ind. ${ }^{-1} \mathrm{~h}^{-1}$ in CIII and again from CIII to adult females (with a wet weight of $1.370 \pm 0.096 \mathrm{mg}$ and a respiration rate of $1.378 \pm 0.376 \mu \mathrm{g} \mathrm{O}$ ind $^{-1} \mathrm{~h}^{-1}$ ); the slopes of the regressions are 0.4 and 1.14 , respectively.

\section{DISCUSSION}

\section{Field observations}

Our results showed that during the period from 2005 to 2008 the total abundance of Calanus euxinus in the Marmara Sea near the Prince Islands varied from 30 to 1260 ind. $\mathrm{m}^{-2}$ (0.15 to 6.3 ind. $\mathrm{m}^{-3}$ ), whilst in the southwestern part of the Black Sea from 2000 to 2007 the total number of this species changed from 1247 to 13790 ind. $\mathrm{m}^{-2}$, or 8.3 to 76.6 ind. $\mathrm{m}^{-3}$ (Isinibilir et al. 2009) and was, on average, 47 times higher than that in the north-eastern Marmara Sea. According to Isinibilir et al. $(2008,2009)$, in the Marmara Sea, maximum abundance of $C$. euxinus was observed in spring, whilst this species nearly disappeared in summer, probably due to high temperatures in the surface and deep layers. On the contrary, in the off-shore regions of the Black Sea, where a cold $\left(6\right.$ to $\left.8^{\circ} \mathrm{C}\right)$ intermediate layer is constantly present, cold-water $C$. euxinus can develop all year round (Sazhina 1987, Vinogradov et al. 1992b).

In April 2005, when the abundance of Calanus euxinus reached its maximum value, copepodite stages from CII to CVI occurred in brackish surface, intermediate and more saline deep layers of the Marmara Sea. The low proportion of carcasses $(3.9 \%)$ found only in

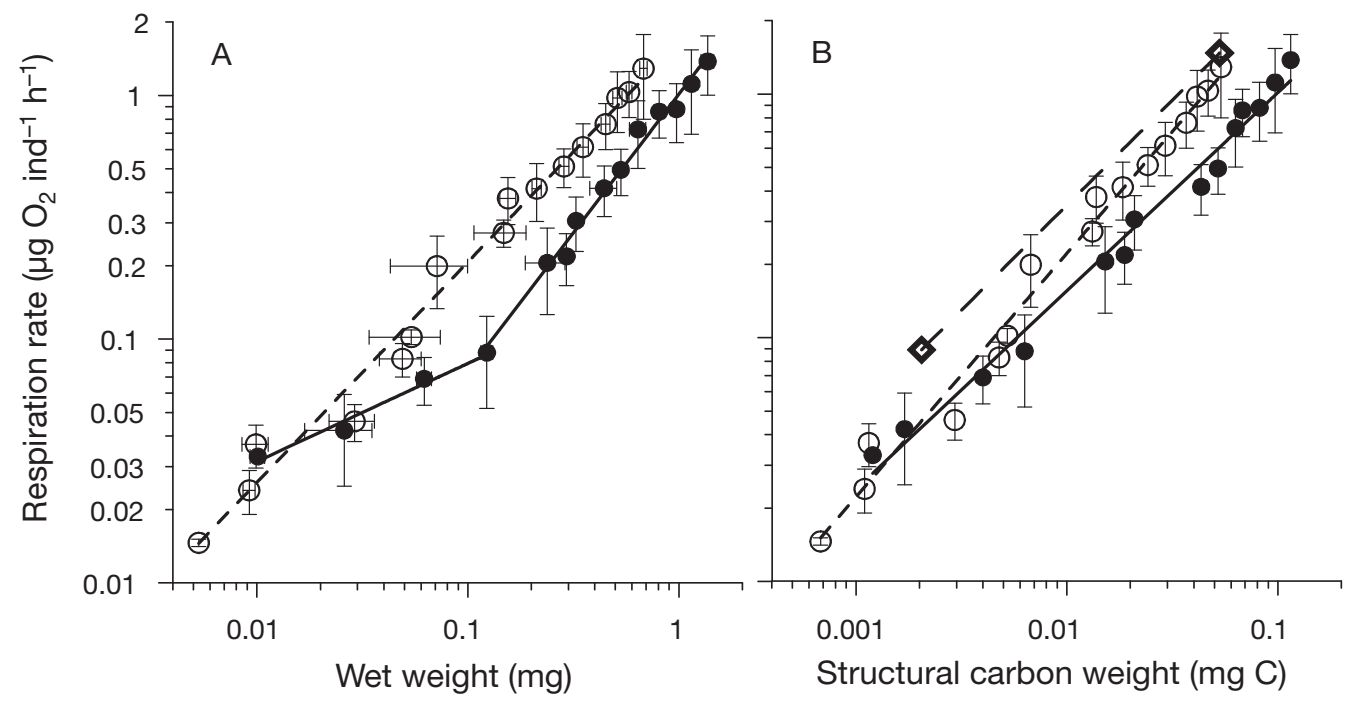

Fig. 8. Calanus euxinus. Respiration rate relative to (A) wet weight and (B) structural carbon weight in nauplii and copepodites from the Black (๑) and Marmara (O) Seas and copepodites of C. pacificus $(\diamond)$ from Puget Sound (Vidal 1980) at $20 \pm 0.5^{\circ} \mathrm{C}$. Values are means \pm SD (bars). Lines: power regression curves; solid for Black Sea individuals, dashed for Marmara Sea individuals, infrequent dashed for C. pacificus 
the 50 to $200 \mathrm{~m}$ layer indicates that $C$. euxinus in the Marmara Sea possess a broad salinity tolerance and can move through the salinity gradient.

\section{Salinity tolerance}

The results of our experiments showed that a shortterm ( $4 \mathrm{~h}$ ) salinity change from 22 to 38.5 psu did not affect locomotor and feeding activity or hatching success in Calanus euxinus from the Marmara Sea. On the contrary, in C. euxinus from the Black Sea, during a gradual salinity increase from 17 to 37 psu over $8 \mathrm{~h}$, the time spent swimming rose, while the frequency of locomotion decreased at the highest salinity values because the limbs began to move slowly (Fig. 3). Probably, the copepods tried to carry out escape behaviour but were constrained by slow-moving limbs which indicate a depressed muscular function. Similar increases in the time spent swimming and decreases in the frequency of locomotion under low oxygen concentration were reported for Black Sea Calanus euxinus in a previous study (Svetlichny et al. 2000). In the estuarine copepod Eurytemora affinis exposed to salinity changes from 0 to $35 \mathrm{psu}$, the increase and decrease of salinity, respectively, increased and decreased the overall swimming activity (Seuront 2006).

In the Black Sea, the swimming activity of Calanus euxinus changes in accordance with circadian rhythms. During daytime, individuals of this species descend to deep layers (Vinogradov et al. 1992a). In the Marmara Sea, C. euxinus exhibiting the same behavioural pattern will experience an acute increase in salinity. One may suggest that the ability to respond to high salinity by increasing locomotion activity allows $C$. euxinus to stay in brackish layers at the surface, prolonging the period of salinity acclimation. According to our results, during a gradual salinity increase from 17 to 37 psu over 30 h C. euxinus females retained the ability to feed and began to lay viable eggs after $5 \mathrm{~d}$ at high salinity. The effect of parental acclimation to salinity on egg hatching success in copepods has been poorly investigated. However, in decapods, egg-carrying females subjected to variable salinity conditions should produce larvae whose salinity tolerance is enhanced (Charmantier et al. 2002).

\section{Growth at different salinity levels}

Variations in salinity can also affect the growth and development time of crustaceans (Anger 2003). For example, salinity increases from 10 to 27 psu (Lee \& Petersen 2002) and from 15 to 25 psu (Devreker et al.
2007 ) resulted in a reduction of development time in the copepod Eurytemora affinis. According to our results, the development time in Calanus euxinus from egg laying to $\mathrm{CIV}$ at $18^{\circ} \mathrm{C}$ and 39 psu was nearly 2-fold shorter (Fig. 6) than that in the experiments of Sazhina (1987) conducted at the same temperature and a salinity of 18 psu (13 and $24 \mathrm{~d}$, respectively). However, the development from CIV to adult females in our study (12 d) took more time compared with the data of Sazhina (1987; $10 \mathrm{~d})$, whilst length increment during this period tended to be lower in preadults kept at 39 psu than in those kept at 18 psu. Therefore, the prosome length of Black Sea females $(2.05 \pm 0.14 \mathrm{~mm}$, mean $\pm \mathrm{SD}$ ), reared in the laboratory at $39 \mathrm{psu}$, was significantly $(\mathrm{p}<0.001)$ lower $(1.3$-fold) than that in the females $(2.62 \pm 0.09 \mathrm{~mm})$ collected from the Black Sea and similar to that of females $(2.01 \pm 0.04 \mathrm{~mm})$ inhabiting the deep layers of the Marmara Sea where the salinity was $38.5 \mathrm{psu}$ and the temperature was $15^{\circ} \mathrm{C}$.

\section{Respiration rate}

Despite the fact that many copepod species are osmoconformers, their respiration rates can be influenced by salinity. For example, the respiration rate of Acartia clausi and A. tonsa increased during salinity changes from 24 to $33 \mathrm{psu}$ and from 2 to $20 \mathrm{psu}$, respectively (Calliari et al. 2006). On the contrary, in Tigriopus brevicornis, an increase in salinity caused a decrease in the oxygen consumption rate and activity as well (McAllen \& Taylor 2001). Reduction of the respiration rate in Calanus finmarchicus was reported for salinity changes from 34 to 21.5 psu (Anraku 1964) and from 34 to 17 psu (Marshall \& Orr 1972).

In our experiments at $20^{\circ} \mathrm{C}$, the weight-specific respiration rate in adult Calanus euxinus collected in the Black Sea (salinity of 17 to 18.7 psu) was 1.5 - to 2-fold lower than in $C$. euxinus living in the Marmara Sea (with a salinity gradient of 18.7 to $38.5 \mathrm{psu}$ ), in $C$. helgolandicus collected in the Ionian Sea (salinity of $39 \mathrm{psu})$, as well as in Black Sea C. euxinus females reared in the laboratory from eggs at 39 psu (Table 2). Weight-specific respiration rates in females captured in the deep layers of the Black and Marmara Seas and maintained at high salinity were higher than those of Black Sea females living at low salinity, independent of the experimental salinity. This is probably due to a significantly higher level of basal metabolism in the females inhabiting high-saline layers, because we did not find any differences in the locomotor parameters of active individuals from the Black and Marmara Seas. The ratios between total metabolism and basal metabolism amounted to 2.6 and 2.4 in the females from the Black and Marmara Seas, respectively, which corre- 
spond to time spent swimming of about $50 \%$ (Svetlichny \& Hubareva 2005) or mean daily time spent swimming at $20^{\circ} \mathrm{C}$ (Svetlichny \& Yarkina 1989). One may suggest that the difference between metabolic rates in C. euxinus females from the Black and Marmara Seas are due to the developmental acclimation to various salinities in their environment.

On the contrary, the weight-specific respiration rates in nauplii and CIs from these areas were similar (Fig. 8). We found a significant difference between the metabolic rates of the Black and Marmara Seas Calanus euxinus only in the copepodite stages from CIII through CVI. Progressive divergence in length, weight and lipid content for CIII was reported by Isinibilir et al. (2009). This is probably due to the ability of late copepodite stages of $C$. euxinus in the Black Sea to migrate daily to cold hypoxic layers, saving energy that can be used for growth (Svetlichny et al. 2009).

In Black Sea Calanus euxinus the carbon weight of metabolically inert wax esters accumulated in the oil sac and reached $50 \%$ of the carbon body weight (Svetlichny et al. 2009), whilst in the Marmara Sea, late copepodite stages were not able to form large amounts of wax esters (Svetlichny et al. 2006). Therefore, use of structural carbon weight instead of wet or dry body weight appears to be more appropriate when comparing the metabolic rates in Calanus spp. with different contents of either metabolically active or inert body compounds. After converting wet weight to structural carbon weight, ontogenetic changes in the respiration rate of Black Sea $C$. euxinus from nauplii to adults were expressed using the allometric equation: $R=$ $6.6 \mathrm{SCW}^{0.81}\left(\mathrm{r}^{2}=0.99\right)$, whilst the respiration rate of Marmara See $C$. euxinus was determined with $R=$ $22.1 \mathrm{SCW}^{0.999}\left(\mathrm{r}^{2}=0.98\right)$. Consequently, metabolic rates in the Marmara Sea C. euxinus females were 2.5 -fold higher than those in Black Sea copepodites with similar SCW, or similar to Black Sea females with 2.2-fold higher SCW. As long as the temperature coefficients $\left(Q_{10}\right)$ in $C$. euxinus from the Black and Marmara Seas are close (Table 3 ), we consider the salinity to be the factor behind the difference in metabolic rates. In fact, in comparison with Black Sea C. euxinus, higher rates of respiration were found in C. helgolandicus females from the Ionian Sea at 39 psu (see Table 2) and in copepodites and females of the closely related species $C$. pacificus from Puget Sound at $\sim 30$ psu (Vidal 1980), with similar SCW (Fig. 8B) calculated taking into account the SCW/DW ratio by Rey-Rassat et al. (2004). In nauplii of Eucalanus pileatus collected from the shelf off the south-eastern United States (Köster et al. 2008), respiration rate $\left(\sim 0.043 \mu \mathrm{g} \mathrm{O} \mathrm{O}_{2}\right.$ ind. $\left.^{-1} \mathrm{~h}^{-1}\right)$ was also 1.3-fold higher than that in nauplii of $C$. euxinus $\left(0.033 \pm 0.0058 \mu \mathrm{g} \mathrm{O} \mathrm{O}_{2}\right.$ ind. $\left.^{-1} \mathrm{~h}^{-1}\right)$ with a similar body length of $0.6 \mathrm{~mm}$.

\section{CONCLUSIONS}

In summary, our results suggest that stenohalinic Black Sea Calanus euxinus, which penetrate the Marmara Sea, with its pronounced salinity gradient, through the Bosphorus, can form a seasonal population there. The ability to increase locomotor activity in response to salinity changes allows C. euxinus to periodically adapt to high salinity, ascending to surface brackish layers after sinking to a deep zone of more saline waters in the Marmara Sea. Long-term parental salinity acclimation facilitates the survival of eggs descending through the salinity gradient of the Marmara Sea, from the brackish upper layers to the highsaline strata, or eggs laid in deep waters. However, high temperature and salinity of the layers below 15$20 \mathrm{~m}$ accelerate the development and depress the growth rate of preadult and adult $C$. euxinus in the Marmara Sea. Length and weight increments in these stages decrease, probably due to an increase in the respiration rate during development at high salinity. Consequently, mainly small-sized females and males with or without a small oil sac (Svetlichny et al. 2006, Isinibilir et al. 2009) inhabit the Marmara Sea. Nevertheless, the body size and respiration rate in nauplii and early copepodite stages developed from eggs laid by small females from the Marmara Sea are the same as those in individuals from the Black Sea. This phenomenon confirms the Black Sea origin of the C. euxinus population in the north-eastern part of the Marmara Sea.

Acknowledgements. The present study was partly supported by a TUBITAK (Turkish Scientific Technical Research Council)—NASU (National Academy of the Ukraine) joint project (107Y001) and by NATO Linkage Grants ESP NUKR 983036.

\section{LITERATURE CITED}

Anger K (2003) Salinity as a key parameter in the larval biology of decapod crustaceans. Invertebr Reprod Dev 43: $29-45$

Anraku M (1964) Influence of the Cape Cod canal on the hydrography and on the copepods in Buzzards Bay and Cape Cod Bay, Massachusetts. II. Respiration and feeding. Limnol Oceanogr 9:195-206

Benli HA, Tarkan AN, Sever TM (2001) Comparison of the mesozooplankton composition the southwestern Black Sea, Sea of Marmara and eastern Aegean Sea. Turk J Mar Sci 7:163-179

Besiktepe S (2001) Diel vertical distribution, and herbivory of copepods in the south-eastern part of the Black Sea. J Mar Syst 28:281-301

Besiktepe ST, Sur HI, Ozsoy E, Latif MA, Oguz T, Unluata U (1994) The circulation and hydrography of the Marmara Sea. Prog Oceanogr 34:285-334

Calliari D, Andersen CM, Thor P, Gorokhova E, Tiselius P (2006) Salinity modulates the energy balance and repro- 
ductive success of co-occurring copepods Acartia tonsa and A. clausi in different ways. Mar Ecol Prog Ser 312: $177-188$

Charmantier G, Giménez L, Charmantier-Daures M, Anger K (2002) Ontogeny of osmoregulation, physiological plasticity, and larval export strategy in the grapsid crab Chasmagnathus granulata (Crustacea, Decapoda). Mar Ecol Prog Ser 229:185-194

Devreker D, Souissi S, Forget-Leray J, Leboulenger F (2007) Effects of salinity and temperature on the post embryonic development of Eurytemora affinis (Copepoda; Calanoida) of the Seine estuary: a laboratory study. J Plankton Res 29:i117-i133

Fleminger A, Hulsemann K (1987) Geographical variation in Calanus helgolandicus s.l. (Copepoda, Calanoida) and evidence of recent speciation of the Black Sea population. Biol Oceanogr 5:43-81

Ikeda T, Kanno Y, Ozaki K, Shinada A (2001) Metabolic rates of epipelagic marine copepods as a function of body mass and temperature. Mar Biol 139:587-596

Isinibilir M, Kideys A, Tarkan A, Yilmaz N (2008) Annual cycle of zooplankton abundance and species composition in Izmit Bay (the northeastern Marmara Sea). Estuar Coast Shelf Sci 78:739-747

Isinibilir M, Svetlichny LS, Hubareva ES, Ustun F, Yilmaz NI, Kideys AE, Bat L (2009) Population dynamics and morphological variability of Calanus euxinus in the Black and Marmara Seas. Ital J Zool 76:403-414

Köster M, Krause C, Paffenhöfer G (2008) Time-series measurements of oxygen consumption of copepod nauplii. Mar Ecol Prog Ser 353:157-164

Lee CE, Petersen CH (2002) Genotype-by-environment interaction for salinity tolerance in the freshwater invading copepod Eurytemora affinis. Physiol Biochem Zool 75: 335-344

Marshall SM, Orr AP (1972) The biology of a marine copepod. Springer-Verlag, New York

McAllen R, Taylor A (2001) The effect of salinity change on the oxygen consumption and swimming activity of the high-shore rockpool copepod Tigriopus brevicornis. J Exp Mar Biol Ecol 263:227-240

Papadopoulos LN, Peijnenburg KTCA, Luttikhuizen PC (2005) Phylogeography of the calanoid copepods Calanus helgolandicus and C. euxinus suggests Pleistocene divergences between Atlantic, Mediterranean, and Black Sea populations. Mar Biol 147:1353-1365

Rey C, Harris R, Irigoien X, Head R, Carlotti F (2001) Influence of algal diet on growth and ingestion of Calanus helgolandicus nauplii. Mar Ecol Prog Ser 216:151-165

Rey-Rassat C, Bonnet D, Irigoien X, Harris R, Head R, Carlotti F (2004) Secondary production of Calanus helgolandicus in the western English Channel. J Exp Mar Biol Ecol 313: $29-46$

Sazhina LI (1987) Reproduction, growth, productivity of marine Copepoda. Naukova Dumka, Kiev (in Russian)

Editorial responsibility: Matthias Seaman,

Oldendorf/Luhe, Germany
Seuront L (2006) Effect of salinity on the swimming behaviour of the estuarine calanoid copepod Eurytemora affinis. J Plankton Res 28:805-813

Stepanov VN, Svetlichny LS (1981) The studies on hydromechanic characteristics of planktonic copepods. Naukova Dumka, Kiev (in Russian)

Svetlichny LS (1983) Calculation of the biomass of planktonic copepods using the coefficients of proportionality between volume and linear dimensions of the body. Ehkol Morya 15:46-58 (in Russian)

> Svetlichny LS, Hubareva ES (2005) The energetics of Calanus euxinus: locomotion, filtration of food and specific dynamic action. J Plankton Res 27:671-682

Svetlichny LS, Yarkina IY (1989) Locomotion rhythms in Calanus helgolandicus (Crustacea, Copepoda). Zoologichesky Zhurnal 68:50-55 (in Russian)

Svetlichny LS, Hubareva ES, Arashkevich EG (1998) Physiological and behavioural response to hypoxia in active and diapausing stage V copepodites of Calanus euxinus. Arch Hydrobiol Spec Issues Adv Limnol 52:507-519

Svetlichny LS, Hubareva ES, Erkan F, Gucu AG (2000) Physiological and behavioral aspects of Calanus euxinus females (Copepoda, Calanoida) during vertical migration. Mar Biol 137:963-971

Svetlichny LS, Kideys A, Hubareva E, Besiktepe S, Isinibilir M (2006) Development and lipid storage in Calanus euxinus from the Black and Marmara Seas: variabilities due to habitat conditions. J Mar Syst 59:52-62

Svetlichny LS, Yuneva TV, Hubareva ES, Schepkina AM and others (2009) Development of Calanus euxinus during spring cold homothermy in the Black Sea. Mar Ecol Prog Ser 374:199-213

Svetovidov AN (1964) Fish of the Black Sea. Nauka, Moscow (in Russian)

Tarkan AN, Erguven H (1988) The main copepod species of Marmara Sea. Istanb Univ J Aquat Prod 2:71-81 (in Turkish with English abstract)

Tarkan AN, Isinibilir M, Tarkan AS (2005) Seasonal variations of the zooplankton composition and abundance in the Istanbul Strait. Pak J Biol Sci 8:1327-1336

> Unal E, Frost BW, Armbrust V, Kideys AE (2006) Phylogeography of Calanus helgolandicus and the Black Sea copepod Calanus euxinus, with notes on Pseudocalanus elongatus (Copepoda, Calanoida). Deep-Sea Res II 53: 1961-1975

- Vidal J (1980) Physioecology of zooplankton. III. Effects of phytoplankton concentration, temperature and bogy size on the metabolic rate of Calanus pacificus. Mar Biol 56: 195-202

Vinogradov ME, Arashkevich EG, Ilchenko SV (1992a) The ecology of the Calanus ponticus population in the deeper layer of its concentration in the Black Sea. J Plankton Res 14:447-458

Vinogradov ME, Sapozhnikov VV, Shushkina EA (1992b) The Black Sea ecosystem. Nauka, Moskow (in Russian)

Submitted: July 9, 2009; Accepted: December 22, 2009

Proofs received from author(s): March 26, 2010 